CMR College of Engineering \& Technology is Sponsored by MGR Educational Society, which has established in 2002. The College is situated on Hyderabad - Nagpur National Highway (Medchal Road), Andhra green and free of pollution. The college endeavors to impart Quality Technical Education and to meet the challenge imposed on, by being in tune with the fast changing Technology \& Globalization.

Since 2006, Department of Master in Business Administration at CMR has been building individuals with the capability to think act and lead in an increasingly complex business world. CMR Strongly believes in the change that individuals can bring about in the world and in themselves, when empowered with the knowledge to analyze the world the confidence to act on their decisions and perseverance to lead others in pursuit of change. It provides a platform to building a strong society and nation

About Sumedha Journal of Management aims at promoting and disseminating relevant, high quality research in the field of management. It is a double blind reviewed referred academic quarterly journa focuses on publishing scholarly articles from the areas of management, management principles, recent inventions in management, company management, financial management, human resources, accounting, marketing, operations management, human resource management, statistics, international business, information technology, environment, risk management, globalization and related areas. Asian journal o management research seeks original manuscripts that identify, extend, unify, test or apply scientific and multi-disciplinary knowledge concerned to the management field. The journal endeavors to provide forum for academicians, scholars and practitioners.

The following types of Papers are considered for publication

1. Original research works in the above-mentioned fields.

2. Surveys, opinions, abstracts and essays related to Operations research.

3. Few review papers will be published if the author had done considerable work in that area.

4. Case studies related to management domain.

Submission of Articles Authors are invited to submit their research articles, review papers, case studies in properly formatted file as per the author guidelines to editor@cmrcetmba.in mentioning the name of the journal or through the submission.

Department of Master of Business Administration CMR COLLEGE OF ENGINEERING \& TECHNOLOGY

An UGC Autonomous Institution

(Approved by AICTE, permanently affiliated to JNTU, Hyderabad)

(NAAC Accredited Institution with 'A' Grade)

Kandlakoya (V), Medchal Road, Hyderabad- 501401

Cell: 9248727208

email:editor@cmrcetmba.in

www.cmrcetmba.in
Referred Journal of CMR College of Engineering \& Technology
Azhar Assankutty

Faresa Fatima Sudershan Kuntluru

Sushma Sharma Ajay Kumar Sharma

M. Seema

A.R. Aryasr

A. Prabhu Kumar

Dr. Pothuraju Vijaya Lakshmi

K. Swapna
Does Corporate Governance Disclosure Practice Impact Firm Performance in India?

Modeling the Link between High Performance Work Based Practices and Talent Retention in IT Companies - A Global Prospective

Linkages among Constructs Reflecting Entrepreneurial Intentions with Special Reference to Undergraduate \& Postgraduate Students of Business Administration

Digital Transactions Impact of BTI with Reference to HDFC Bank

mpact of Employee Absenteeism on Logistics Efficiency (With Reference to Select Companies of the Logistic Sector)
UGC Approval Journal (Serial No: 46802)

Indexed in Indian Citation Index (ICI), PROQUEST DATA BASE, Google Scholar JUSER DATA BASE, MIAR Data Base Index Copernicus value 59.11, ISRA JOURNAL FACTOR 4.018, Sjifactor Impact factor 4.339, International Scientific Indexing Impact factor 1.332 
Patrons

Ch. Malla Reddy, Chairman CMRGI

Secretary \& Correspondent

\section{Chief Editor}

Dr. A Kotishwar,

Professor \& HOD, Dep of MBA, CMRCET
Advisory Board

Dr. N. Satyanarayana, Director - (Academics), CMRG Major Dr. V.A. Narayana, Principal - CMRCET

\section{Managing Editors}

Dr. P. Hima Bindu, Profess Dr. P. Alekhya, Associate Professor

Assistant Managing Editors

Dr. P. Vijaya Lakshmi, Associate Professor

\section{Editorial Board}

S.No Name

Prof. Mohd Akbar Ali Khan

Dr. M Muninarayanappa

Dr. S Gurusamy

Dr. Mohammed Jahangir Ali

Prof. Renu Jatana

Prof. Vani N Laturkar

Dr. Vivek Deolankar

Dr. Sindhu

Dr Mary Jessica

10 Prof. Walmik K. Sarwade

11 Prof. (Dr.) Sanket Vij

12 Dr. Sudershan Kuntluru

13 Prof. GS Batra

14 Dr. Chetan Srivastava

15 Dr. Vanita Tripathi

Dr. Rachappa Shette

Dr. A.A. Ananth

Dr. Faresa Fatima

Address

Honorable Former Vice-Chancellor. Telangana University, Nizamabad, Telangana

Professor, Department of Commerce, Bangalore University

Professor \& Head, Department of Commerce, University of Madras, Chennai

Head \& Associate Professor, AL Buriami University College, Oman

Professor \& HOD, Department of Banking \& Business Economics,

Mohan Lal Sukhadia University, Udaipur, Rajasthan.

Director, School of commerce \& Management Science,

Swami Ramanand Teerth, Marathwada University, Nanded

Head, Department of Commerce. University of Mumbai

Professor, SMS, JNTUH

Professor, School of Management Studies, University, Hyderabad

Professor Department of Commerce, Dr. Babasaheb Ambedkar Marathwada University, Aurangabad

Dean \& Chairperson, Faculty of Commerce\& Mgt, Bhagat Phool Singh Mahila Vishwavidyalaya, Khanpur Kalan, Haryana

Associate Professor, Indian Institute of Management Kozhikode, Kerala

Professor \& Head, School of Management Studies, Punjabi University, Patiala, Punjab, India

Associate Professor, School of Management Studies, University, Hyderabad

Associate Professor, Department of Commerce, Delhi School of Economics, University of Delhi

Professor Finance, Indian institute of management Kozhikode, Kerala

Associate Professor, Department of Business Administration

Annamalai University, Tamil Nadu.

Associate Professor Department of Business Administration and

Accounting, Al-Buraimi University College

(Affiliated to California State University, Northridge, USA),

\section{GUIDELINES FOR AUTHORS}

1. The cover page of the article/research paper should include the title of the paper, Author's name Designation, organization with the address, contact number \& email address.

2. Abstract of not more than 200 words outlining the purpose of study should be presented on a separate sheet along with 5-6 keyword immediately preceding the text.

3. Name(s) of the author(s) should not appear anywhere in the entire text other than the cover page.

4. All the manuscript will be sent for blind review process, the corresponding author will be informed by the editor about acceptance or rejection of the manuscript within a period of time. On acceptance of the manuscript, the modifications suggested by the reviewers are to be incorporated by the author with in a period of 10 days and send copy of the revised manuscript again.

5. The editor reserves the right to modify or improve the manuscript as per the standard of journal.

6. The copyright of the research papers published in the journal shall lie with the publisher.

7. The authors whose papers are selected for publication shall make a subscription (Rs. 2500) for annual of the printed edition of the journal per author.

8. Copies of the journal are available by way annual subscription (Rs. 2,500 for annual or Life Time Rs. 10,000).

\section{General Information about submission}

1. For Submission:

- Covering Letter: Title of the Paper, Author's Name, Designation, Organizations, Official Address, Personal Address, Contact Numbers (Official \& Personal) and e-mail address

- Abstract: should contain - objectives, Research Questions / Hypothesis, Methodology, findings and 5-6 keywords. Words limit - 250-300 words.

2. Full Paper

- Format : A4 size, Ms-word

- Word Limit : Not to exceed 5000 words

- Font : Times New Roman

- Size : Title - 18 , Heading - 14 , Text-12

- Line spacing : 1.5

3. Declaration : Author must declare originality of work. The article should not have been published or be submitted for publication else where.

4. Editorial Board's decision will be final.

5. The copyright of all accepted papers will vest with dept. of MBA - CMRCET

\section{Address for corespondence:}

\section{SUMEDHA Journal of Management}

Dr. A Kotishwar

Chief Editor,

HOD, Dept of Master in Business Administration

CMR College of Engineering \& Technology, Kandlakoya (v),

Medchal Road, Hyderabad.

Telangana, India.

E-mail: editor@cmrcetmba.in

Website: www.cmrcetmba.in 


\section{SUMEDHA-Journal of Management}

Referred Journal of CMR College of Engineering \& Technology

October-December 2019, Volume 8, No. 4

\begin{tabular}{|c|l|l|c|}
\hline $\begin{array}{c}\text { S. } \\
\text { No. }\end{array}$ & \multicolumn{1}{|c|}{ Title } & \multicolumn{1}{|c|}{ Authors } & \multicolumn{1}{|c|}{$\begin{array}{c}\text { Page } \\
\text { No. }\end{array}$} \\
\hline 1. & $\begin{array}{l}\text { Does Corporate Governance Disclosure Practice } \\
\text { Impact Firm Performance in India? }\end{array}$ & $\begin{array}{l}\text { Azhar Assankutty, } \\
\text { Faresa Fatima, } \\
\text { Sudershan Kuntluru }\end{array}$ & $1-14$ \\
\hline 2. & $\begin{array}{l}\text { Modeling the Link between High Performance } \\
\text { Work Based Practices and Talent Retention in IT } \\
\text { Companies - A Global Prospective }\end{array}$ & $\begin{array}{l}\text { Sushma Sharma, } \\
\text { Ajay Kumar Sharma }\end{array}$ & $15-31$ \\
\hline 3. & $\begin{array}{l}\text { Linkages among Constructs Reflecting } \\
\text { Entrepreneurial Intentions with Special Reference } \\
\text { to Und ergraduate \& Postgraduate Students of } \\
\text { Business Administration }\end{array}$ & $\begin{array}{l}\text { M. Seema, } \\
\text { A.R. Aryasri }\end{array}$ & $32-45$ \\
\hline 4. & $\begin{array}{l}\text { Digital Transactions Impact of BTI with Reference } \\
\text { to HDFC Bank }\end{array}$ & $\begin{array}{l}\text { V.V. Nagamani, } \\
\text { A. Prabhu Kumar }\end{array}$ & $46-55$ \\
\hline 5. & $\begin{array}{l}\text { Impact of Employee Absenteeism on Logistics } \\
\text { Efficiency (With Reference to Select Companies } \\
\text { of the Logistic Sector) }\end{array}$ & $\begin{array}{l}\text { Dr. Pothuraju Vijaya } \\
\text { Lakshmi, } \\
\text { K. Swapna }\end{array}$ & $56-64$ \\
\hline
\end{tabular}




\section{Chief Editor Message}

As SUMEDHA Journal of Management Dourteenth issue, We look forward to the momentous growth of our Journal, increasing in their appeal, readership and relevance to the fast-changing world of Business Management. During these six years journey our journal has been critically evaluated by various institutions with similar line of interest and faculty fraternity. We have been consistently seeking advice from experts to continuously improve the quality of the journal. Our journal has got UGC Approval Journal (Serial No : 46802 ), Indexed in Indian Citation Index (ICI), PROQUEST Database, Google scholar JUSER Database, MIAR Data Base, Index Copernicus value 59.11, ISRA Journal Factor 4.018, Sjifactor Impact factor 4.339, International Scientific Indexing Impact factor 1.332. On behalf of the Management, Editorial Board and Editorial Team, I express my profound gratitude to all our authors, reviewers, readers and patrons for offering their overwhelming support and I anticipate a continued and lively partnership for years to come.

All of us recognize the necessity for change, which results in progress. It gives way to new ideas and perspectives reflecting the current and emerging environment, which builds on the solid foundations of the past.

Last but not least valuable would be your response and suggestions on this issue. Kindly send us your views so that we can keep on upgrading our journal.

Thanking you 


\title{
Modelling the Link between High Performance Work Based Practices and Talent Retention in IT Companies - A Global Prospective
}

\author{
Sushma Sharma*, Ajay Kumar Sharma** \\ * Research Scholar (Thesis submitted, MDU, Rohtak), Email: sushma2595@yahoo.com, \\ ${ }^{* *}$ Assistant Professor, MERI College, New Delhi, Email: ajaysharmapuru@rediffmail.com \\ Assistant Professor, T.I.TES., Bhiwani
}

\begin{abstract}
High performance work practices are highly important not only in human resource literature but also for the organizations to manage its workforce. This study develops a conceptual framework in which high performance work based practices affect talent retention on the basis of review of literature. The conceptual framework composed of independent variable and dependent variables. In a sample of 350 IT professional from Delhi $\mathcal{E}$ NCR of IT companies, it was found that high performance work based practices relate positively to talent retention. The main objective of this study is to examine the impact of high performance work based practices on talent retention in IT companies. Adopted questionnaire was used to collect the data. In order to analyse the data SPSS version 21 was used for data analysis. Regression analysis was used for testing of hypothesis in this study.From the regression analysis the impact of high performance work based practices was found significant on talent retention. Finally, this study concluded with discussions, practical implications and limitations. The result suggested that high performance work based practices are influenced by the set of innovative $H R$ practices which provide a basis for the organization to gain competitive advantage. From the findings of the study there is sufficient background to recommend to all IT companies should incorporate these practices in their organization as a matter of concern. Hence this study is highly significant and useful for the IT companies.
\end{abstract}

Key words: High performance work based practices, innovative human resource practices, talent retention and competitive advantage.

JEL Classification: J24, M12, L8,86
Publishing Chronology PAPER SubMission Date : August 5, 2019;

PAPER SENT BACK FOR REVISION : September 7, 2019;

Paper Acceptance Date :

NOVEMber 5, 2019

Reference to this paper should be made as follows:

Sushma Sharma*, Ajay Kumar Sharma (2019),

"Modelling the Link between High Performance Work Based Practices and Talent Retention in It Companies - A Global Prospective" SUMEDHA Journal of Management, Vol 8, No 4, PP (15-31) 
Modelling the Link between High Performance Work Based Practices and Talent Retention in IT Companies - A Global Prospective Sushma Sharma*, Ajay Kumar Sharma**

\section{INTRODUCTION}

High performance work based practices have gradually replaced old HR practices. These are innovative human resource practices that help an organization to manage workforce. HPWBP are unconventional work practices which shows a direct relationship between innovative human resource practices and company growth. Global innovative human resource practices involve the worldwide management of people, not just the expatriates. It provides an organized framework for development and management of people. The problems in implementation of Global innovative HR practices are related to managing of cultural diversity and performance appraisal of expatriates. The important trend that effect organization is technology. Studies have shown that the companies which are rated high by their employees can attract and retain the best talent in IT sector. Due to technological advancement, manufacturing industries will suffer a lot because of their replacement with robotics. this study can help IT industry to understand the gap and fill it for overall improvement. The role of IT sector in economic development is constantly increasing. So, it becomes important to select the best innovative human resource practices to manage IT professional.The study is based on IT professionals of the IT companies in Delhi \& NCR.

The concept of best practicesor high performance work based practices is one of the innovative human resource practices where the employees are directly required to involve themselves to exhibit their talent for the growth of the organization. Their talent will go long way for their growth in the future. High performance work system was evolved in 1980's in US. US manufacturer realized in 1980's that old human resource practices are not feasible because the world market is changing very rapidly. In the world of competition, the business environment has put a lot of pressure on the human resource management to justify its existence. The human resource department should work to find right talent and must work hand to hand with the business houses. HRM must demonstrate that it can add value for the organization in all context.If human resources are not properly coupled with other resources, viz., capital, material, etc., then organizations will become unproductive and non-profitable Reddy and Reddy (2019)Recently new trends have taken place in the field of human resource management. These trends are highlighting the importance of human resources.Human resource practice aims at effective utilization of manpower for accomplishing the organization objectives. The vitality of the organization depends upon the quality of its human resource Padala (2014) It has been changed from industrial relation to personnel management and was recently to strategic human resource management and human resource development. Further changes are taking place and in future new challenges will arise before human resource management.

\section{High Performance Work Based Practices}

Sung and Ashton (2005) noted that: The term 'high-performance work based practices' (HPWBP) is the one most commonly used in public and private sector and it is therefore adopted in this study. It is recognized that employee involvement, human resource practices 
and employee commitment and commitment practices are important factors in the pursuit of high performance. As per the (Sung et. al, 2005) HPWBP involves three broad categories i.e. Human resource practices, Employee involvement and Reward and commitment practices. The aspects which were provided by (Sung et. al, 2005) are used for the study, as researcher found these aspects are most suitable for the study. Firstly, it is important to understand the three broad categories which comes under HPWBP.

- Employee involvement practices (EIP)

- Human resource practices(HRP)

- $\quad$ Reward and Commitment practices (RCP)

\section{TALENT Retention IN IT COMPANIES}

IT sector in India shows a high mobility rate among IT professionals. Various studies shown that $74 \%$ of IT professionals are open for switching of one job and looking for another one even when they report to be satisfied with their current job. The highest rate of mobility is among younger IT professionals and those who are at junior level. A study conducted by Glassdoor and Harvard Business Review in 2012 found that the workers who have a long stay in the organization are more willing to change their job for career prospectus. Retaining of talent is the primary concern of IT companies. Top management and HR departments spend large amount of time and money to motivate their employees to have stay in the organization. Talent retention is proved to be beneficial for the development of the organization. Losing key employees means a great loss to departments as well as the organization. Exit interview is a tool by which departing employees provide valuable information that can used to retain remaining employees. Majority of the organizations are employing monetary and non-monetary strategies to retain their employees.

\section{Conceptual Framework of the Study}

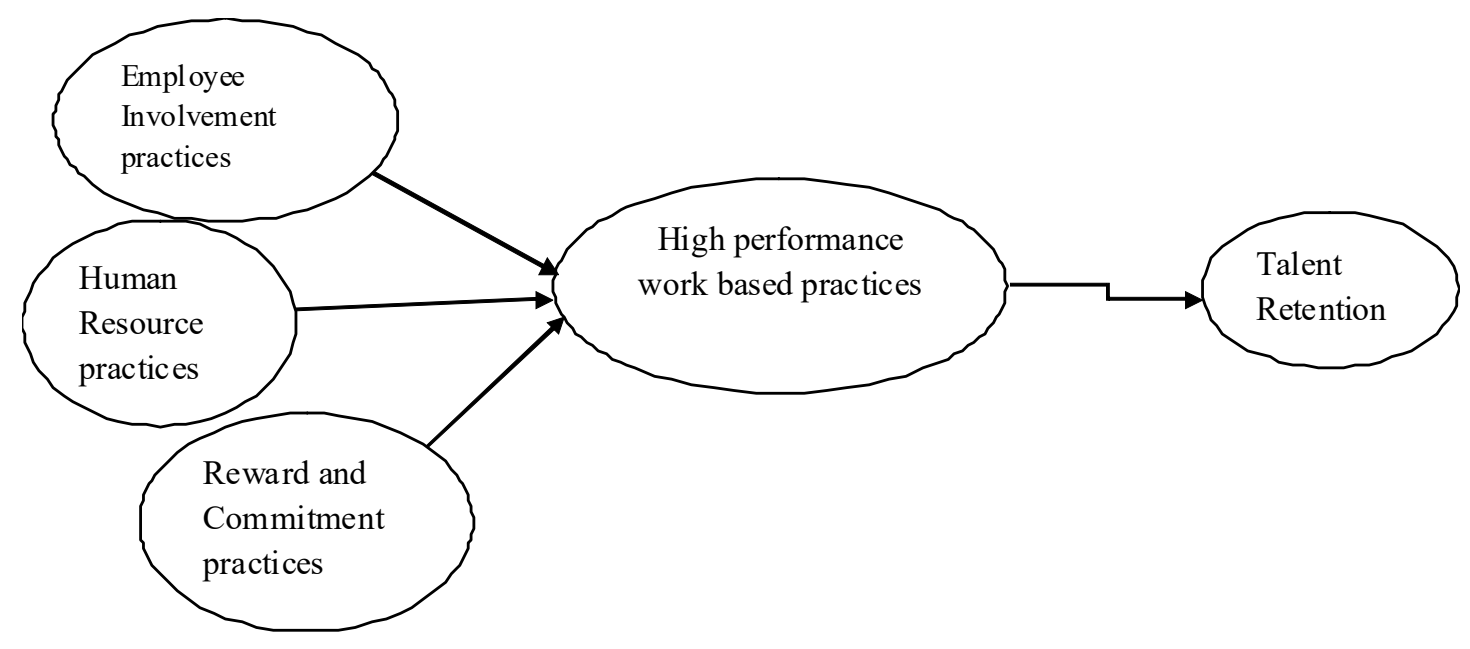


Modelling the Link between High Performance Work Based Practices and Talent Retention in IT Companies - A Global Prospective Sushma Sharma*, Ajay Kumar Sharma**

As per the (Sung et. al, 2005) HPWBP involves three broad categories i.e. Human resource practices, Employee involvement and Reward and commitment practices. The aspects which were provided by (Sung et. al, 2005) are used for the study, as researcher found these aspects most suitable for the study. The conceptual framework of the study was constructed on the basis of two variables including high performance work based practices employee considered and rated as independent variable (IV) which is broadly categorized into three parts: i) employee involvement practices ii) human resource practices and iii) reward and commitment practices and talent retention was studied as dependent variable (DV). These two variables were conceptualized on the basis of previous studies. Previous literature has shown that if right people are placed for the right job, trained them accordingly whenever needed and reward them according to their performance tends to exhibit positive behaviour at the work place.

\section{Statement of the Problem}

The entry of the global players in IT industry has created huge challenge for the Indian IT companies. Owing to this, Indian company has to adopt new human resource practices in today's competitive world. It is universally accepted that employees are valuable asset of the organization and have great potential to improve the organization as a whole. HR manager would target skilled and productive work force. The purpose of the research is to observe the relationship between high performance work based practices and talent retention. This study focuses on impact of high performance work based practices on talent retention. There is no known a study to ascertain HPWBP in IT companies in Delhi \&NCR. The study aims to know the impact of high performance work based practices in IT companies. Hence this study is directed towards regarding innovative HR practices and its outcome to find solution to meet the challenges. A lot of attention has been done by researcher in the area of HPWBP and its impact on employee outcomes. The title of the study is "Model of high performance work based practices and talent retention - A global perspective".

\section{REVIEW OF Literature}

\begin{tabular}{|l|l|}
\hline 2.1 & Studies related to High performance work based practices \\
\hline 2.2 & Studies related to relationship between HPWBP and Talent Retention \\
\hline 2.3 & Gap Analysis \\
\hline
\end{tabular}

\subsection{STUDiES RELATED TO High PERFORMANCE WORK BASED PRACTICES}

High performance work based practices are termed as 'best' HR practices that enhance the skills of the workforce, encourage to participation and involve in important matters (Sun, Aryee, \& Law, 2007). Tamkin (2004) defined HPWPs as the systematic procedures used to test the efficacy of human resources on firm's performance. Zhang and Li (2009) identified a 
combination of six HPWBPs consist of training, participation, well defined jobs, promotion, performance appraisal and sharing of profits. As per the (Sung et. al., 2005) HPWBP involves three broad categories i.e. Human resource practices, Employee involvement and Reward and commitment practices. The aspects which were provided by (Sung et. al., 2005) are used for the study, as researcher found these aspects most suitable for the study.

Appelbaum et.al. (2000) - has done his study in manufacturing units covering 4400 employees by using management interviews, plant performance and data survey. Researcher has found that HPWBP has a positive impact on the plant performance. A new system of wages payment has been introduced among the workers, where the variable pay was based on team effort. After introducing this system there was a drastic improvement in the quality of work and quantity manufactured. All the process in the plant were speed up and all the customer orders were delivered on time. In another medical electronic industry HPWBP has shown positive effect on financial performance and productivity. In this study under HPWBP skills of workers enhanced, participation in decision making, organizational relationship, intrinsic rewards, fairness in pay system has been initiated.

Agarwal (2003) - in this today's competitive world innovative HR practices are need of the hour. In the antecedent of HPWBP it was accepted by the researchers and academicians that traditional ways of HR practices cannot be used for a longer duration with the changing needs of the employees. HR practices have great impact on employee behavior, satisfaction, productivity and retention, which ultimately leads to organizational effectiveness. Constant development is required to be competitive in the industry. Industry practitioners also felt the requirement of innovative $H R$ practices to deal with constant competition in term of changing demand of customers and employees.

Sung and Ashton (2005) - A study was conducted on employees in 294 UK companies and it was termed as HPWBP. As per Sung and Ashton these practices are directly linked to organizational productivity. These practices are termed as a 'bundle' of innovative practices. HPWBP involves three broad categories i.e. Human resource practices, Employee involvement and Reward and commitment practices had greater impact on employee satisfaction, productivity and retention. As per Sung and Ashton, employee involvement and reward practices were more effective in managing employees and providing career opportunities.

\subsection{STUDIES RELATED TO RELATIONSHIP BETWEEN HIGH PERFORMANCE WORK BASED PRACTICES AND TALENT RETENTION}

Indian Information Technology Industry is on the stage of intensified competition between the various Players. The main resource in IT companies are manpower which deals with all kind of challenging jobs. Therefore, luring capable employees, developing them in the organization, retaining and maintaining them is a major strategic objective for all the organizations in IT sector. To achieve this objective Human resource departments in IT companies has to take 360-degree action and implementation of HR policies and practices in the organization. With the help of top management, the HR department takes necessary 
Modelling the Link between High Performance Work Based Practices and Talent Retention in IT Companies - A Global Prospective Sushma Sharma*, Ajay Kumar Sharma**

steps to dealt with the new challenges posed by the business environment by developing the innovative Human Resource practices.

Ramlall (2009) - has found in his study that acquisition, development, retention, performance and talent management is the most difficult task for any organization, as large number of options are available in the market for talented workforce. As per this study if companies continue to work as per traditional ways then it will become too difficult to retain the talented people in the organization. New and innovative HR practices needs to implement to retain the people in the organization. Study has also found a significant impact of new HR practices on the retention of the employee, when a employee feel important by the way of recognition and participation they exhibits loyalty towards organization.

Sung- Choon (2013) - suggests that now a day's various companies are opting for innovative HR practices to increase the overall organizational efficiency, performance and employee productivity. In many organization these kind of HR practices are not applied willingly by the management by the regulators also enforce the organization to develop or adopt the new or innovative HR policies and practices, so that employees can also participate in the prosperity of the company. Due to regulatory enforcement it is become inevitable for the management to implement IHRP. In U.S. the innovative Human resource practices which were initiated are 360-degree appraisal, Six Sigma, outsourcing, competency based compensation, group reward system, information sharing etc. IT companies who can be called as global companies feels pressurized to implement these kinds of practices in the organization to deal with the global competitive environment and sustain in the market.

\subsection{Gap ANALYSIS}

In modern era organizations are still rely on contingency approaches because of unaware of applicability of HPWBP in turbulent situations. HPWBP focus on employee involvement which adds value to the organization. Gap in the existing literature disclosed that there is a need to understand the importance of HPWBP in IT Industry. In Indian literature, only one study has been found on HBPWBP on IT industry in Mumbai but none of the studies have been conducted in Delhi-NCR. No research has been conducted on core group like Experienced IT professionals in Delhi NCR region, but this study is exploring the linkage between HPWBP and talent retention in IT companies. Several studies were incorporated in the existing literature for the last two decades and lots of improvements are found in terms of growth and development of IT sector.

\section{Research Methodology}

\section{1 ОвJECTIVE AND HyPOTHESIS OF THE STUDY}

- To study the relationship between high performance work based practices and Talent retention 
Modelling the Link between High Performance Work Based Practices and Talent Retention in IT Companies - A Global Prospective

Sushma Sharma*, Ajay Kumar Sharma**

\section{Null Hypothesis}

- There is no significant impact of employee involvement practices on talent retention w.r.t. IT professionals.

- There is no significant impact of human resource practices on talent retention w.r.t. IT professionals.

- There is no significant impact of reward and commitment practices on talent retention w.r.t. IT professionals.

\subsection{Research Design}

A research design is a framework for carry out research activities. It provides a basis for conducting research. A good research design ensures that the research work is carried out in effective way. In this study, the researcher is keen to know the relationship between dependent variable (talent retention) and independent variables (high performance work based practices, which is broadly categorized into three parts i.e. employee involvement practices, human resource practices and reward \& commitment practices). As this study measure the relationship quantitatively, questionnaire has been used for the collection of primary data.

\subsection{TyPe OF RESEARCH}

The nature of our study is descriptive as descriptive research includes collection of data, organizing, tabulating, depicting and describing the results (Glass \& Hopkins, 1984). In social science we quite often use descriptive research, as it includes surveys and fact-finding enquiries. This research was undertaken because researcher is interested to know the relationship between dependent and independent variables and impact of demographic characteristics such as age, sex, income, qualification and experience. Extensive literature review has been done to identify the variables for the study.

\subsection{Designing of Questionnaire}

Questionnaire has been used for the study. Researcher measured HPWBP statements: HRP (8), EIP (6) and RCP (8) statements were adopted from (Sung et. al, 2005). Talent retention (8) statements were adopted from (Ramsay et. al., 2000). The questionnaire has been divided into three parts where in part one contains employee profile information, second and third part perception based statements representing the variables of the study. The questionnaire has 30 items and each item is measured on five-point Likert scale, ranging from 0 to 5 . The employee profile variables include age, gender, designation, experience and education of the respondents. By the use of Likert scale perception of the respondents can be quantified for further analysis. This questionnaire is used to measure em ployee's responses regarding impact of high performance work based practices on talent retention. 
Modelling the Link between High Performance Work Based Practices and Talent Retention in IT Companies - A Global Prospective Sushma Sharma*, Ajay Kumar Sharma**

Table:1: Questionnaire Structure

\begin{tabular}{|l|l|l|l|}
\hline Section & \multicolumn{1}{|c|}{ Variable Name } & $\begin{array}{l}\text { No. of } \\
\text { Items }\end{array}$ & \multicolumn{1}{|c|}{ Description } \\
\hline Part-A & $\begin{array}{l}\text { Employee Profile } \\
\text { Information }\end{array}$ & $\begin{array}{l}\text { This part contains the information } \\
\text { regarding the Name Optional), Age, } \\
\text { Gender, Education, Designation and } \\
\text { Experience of respondents. }\end{array}$ \\
\hline Part-B & $\begin{array}{l}\text { High Performance } \\
\text { Work Based Practices }\end{array}$ & $\begin{array}{l}\text { 3Sub } \\
\text { variables }\end{array}$ & $\begin{array}{l}\text { This variable indudes three sub } \\
\text { variables, which are: }\end{array}$ \\
\hline & HR Practices (HRP) & $\begin{array}{l}\text { This variable indudes HR related } \\
\text { practices like feedback system, } \\
\text { performance appraisal system, work } \\
\text { ethics, job rotation etc. }\end{array}$ \\
\hline $\begin{array}{l}\text { Employee Involvement } \\
\text { Practices (EIP) }\end{array}$ & 6 Items & $\begin{array}{l}\text { This variable covers all those aspects } \\
\text { which are related to the participation of } \\
\text { an employee in decision making like } \\
\text { information \& scheme sharing, goal } \\
\text { setting, communicationchannel etc. }\end{array}$ \\
\hline $\begin{array}{l}\text { Reward and } \\
\text { Commitment Practices } \\
\text { (RCP) }\end{array}$ & 8 Items & $\begin{array}{l}\text { in this variable reward and commitment } \\
\text { related aspects are included like } \\
\text { increments, incentives, bonus, } \\
\text { promotion etc. } \\
\text { Outcome variable }\end{array}$ & $\begin{array}{l}\text { It includes one variable, which is: } \\
\text { This variable map the perception } \\
\text { regarding the Talent retention in the } \\
\text { organization due to high performance } \\
\text { work based practices. }\end{array}$ \\
\hline Talent Retention (TR)
\end{tabular}

\subsection{SAMPLING}

Sampling is a procedure by which the type of respondent, number of respondent and technique of selecting that respondent is decided. Sampling should be done carefully so that the selected sample represents the actual population of the study.

\section{Universe ANd Population}

Study is conducted in IT (Information Technology) industry in India; hence employees of IT industries located in India can be termed as universe of the study. IT companies of Delhi \& NCR (Near Capital Region) have been covered for the study hence all the employees (IT) of Delhi \& NCR can be called as the population of the study. Data has been collected form IT professional. 


\section{Sample Size And TechniQue}

Eight IT companies (Tata Consultancy Services, IBM, Wipro, NIIT technologies, Hindustan Computers Limited, Infosys, Neerja Software Pvt. Ltd. and HSBC software development Pvt. Ltd) were selected randomly on the basis of market size and profitability of the companies for data collection. All these companies are located in Delhi \& NCR. Data has been collected form 350 IT respondents. As data is collected from the IT professionals and from different companies hence stratified and cluster sampling technique is used. While deciding the individual respondent or at the time of questionnaire distribution convenience or snowball sampling method has been used.

\subsection{Statistical Technique used}

Table :2 Techniques used

\begin{tabular}{|l|l|l|}
\hline Objective Wise & \multicolumn{1}{|c|}{ Purpose } & Technique used \\
\hline Data Testing & Reliability Testing & Cronbach's Alpha \\
\hline Objective & $\begin{array}{l}\text { To study the relation ship between high } \\
\text { performance work based practices and talent } \\
\text { retention } \\
\text { (Depending upon the objective and the } \\
\text { measurement of variables regression method } \\
\text { has been used, as variables are metric in } \\
\text { nature) }\end{array}$ & $\begin{array}{l}\text { Multiple } \\
\text { Regression }\end{array}$ \\
\hline
\end{tabular}

4. Analysis

\subsection{Checking Outliers}

Table no. 3 shows that the value of the skewness and kurtosis for 350 IT professionals which is lying between +2 to- 2 , hence data is free from outliers. 
Modelling the Link between High Performance Work Based Practices and Talent Retention in IT Companies - A Global Prospective Sushma Sharma*, Ajay Kumar Sharma**

Table:3 Descriptive Statistics for 350 IT Professionals

\begin{tabular}{|l|c|c|c|c|c|c|}
\hline \multicolumn{7}{|c|}{ Descriptive Statistics } \\
\cline { 2 - 7 } & & $\mathbf{N}$ & Mean & \multicolumn{2}{c|}{ Skewness } & \multicolumn{2}{c|}{ Kurtosis } \\
\hline Statistic & Statistic & Statistic & Std. Error & Statistic & $\begin{array}{c}\text { Std. } \\
\text { Error }\end{array}$ \\
\hline HRP & 350 & 2.6018 & -.384 & .130 & -.984 & .260 \\
\hline EIP & 350 & 2.2676 & -.041 & .130 & -.983 & .260 \\
\hline RCP & 350 & 2.4950 & -.557 & .130 & -.496 & .260 \\
\hline HPWBP & 350 & 2.4548 & -.512 & .130 & -.864 & .260 \\
\hline TR & 350 & 2.4789 & -.008 & .130 & -.862 & .260 \\
\hline Valid N & 350 & & & & & \\
\hline
\end{tabular}

Sources: Authors Calculations using SPSS 21 Version

\subsection{Reliability Testing}

Table no. 4 shows the reliability of 350 IT professionals which is great as per (Field, 2009) as the values is more than 9 .

Table: 4 Reliability statistics for 350 IT professionals

\begin{tabular}{l|l|}
\hline \multicolumn{2}{|c|}{ Reliability Statistics } \\
\hline Cronbach's Alpha & \multicolumn{2}{|c|}{ No. of Items } \\
\hline .911 & 30 \\
\hline
\end{tabular}

Sources: Authors Calculations using SPSS 21 Version

\subsection{Objective Analysis and Hypothesis testing}

Objective- To study the relationship between high Performance work based practices and talent retention.

Technique used - Multiple Regression analysis

Confidence interval $(\alpha)-95 \%$

\subsubsection{Assumptions fOR APPLying Multiple Regression}

1. No. Autocorrelation: Table no.5 shows that the value of Durbin-Watson is ranging between 2.3 to 2.5 , hence no issues of autocorrelation.

2. Normal distribution of residuals: Normal PP plots no. 1 of regression standardized residual shows that the data is concentrated around the regression line hence the residual values are normally distributed. PP plots is designed for talent retention (TR) of 350 IT professionals. 
3. Homoscedasticity: Scattered plots no.1 has been drawn for standardized predicted value and standardized residual, no pattern in the plot shows that no issue of homoscedasticity. scattered plot is designed for talent retention (TR) of 350 IT professionals.

4. Normality of Data: Normality of these variables has been checked.

5. Multicollinearity: Table no. 7 shows that the VIF (Variable inflation factor) value of all the variables is less than 5 hence variables are free from multicollinearity.

Table: 5 Model Summary of Objective

\begin{tabular}{|c|c|c|c|c|c|c|}
\hline \multicolumn{7}{|c|}{ Model Summary b } \\
\hline \multicolumn{2}{|c|}{ Type of Personnel } & $\mathbf{R}$ & $\begin{array}{c}\mathbf{R} \\
\text { Square }\end{array}$ & $\begin{array}{l}\text { Adjusted } \\
\text { R Square }\end{array}$ & $\begin{array}{c}\text { Std. Error } \\
\text { of the } \\
\text { Estimate }\end{array}$ & $\begin{array}{l}\text { Durbin- } \\
\text { Watson }\end{array}$ \\
\hline 1 IT Professionals & 1 & $.729 \mathrm{a}$ & .531 & .527 & .44509 & 2.317 \\
\hline \multicolumn{7}{|c|}{ a. Predictors: (Constant), RCP, EIP, HRP } \\
\hline \multicolumn{7}{|c|}{ b. Dependent Variable: TR } \\
\hline
\end{tabular}

Sources:Authors Calculations using SPSS 21 Version

Table: 6 ANOVA table of Objective

\begin{tabular}{|c|c|c|c|c|c|c|c|}
\hline \multicolumn{8}{|c|}{ ANOVA a } \\
\hline \multicolumn{3}{|c|}{ Type of Personnel } & $\begin{array}{c}\text { Sum of } \\
\text { Squares }\end{array}$ & df & $\begin{array}{c}\text { Mean } \\
\text { Square }\end{array}$ & F & Sig. \\
\hline \multirow[t]{3}{*}{ IT Professionals } & \multirow[t]{3}{*}{1} & Regression & 77.691 & 3 & 25.897 & 130.726 & $.000 \mathrm{~b}$ \\
\hline & & Residual & 68.544 & 346 & .198 & & \\
\hline & & Total & 146.235 & 349 & & & \\
\hline \multicolumn{8}{|c|}{ a. Dependent Variable: TR } \\
\hline \multicolumn{8}{|c|}{ b. Predictors: (Constant), RCP, EIP, HRP } \\
\hline
\end{tabular}

Sources: Authors Calculations using SPSS 21 Version 
Modelling the Link between High Performance Work Based Practices and Talent Retention in IT Companies - A Global Prospective Sushma Sharma*, Ajay Kumar Sharma**

Table: 7 Coefficient table of Objective

\begin{tabular}{|c|c|c|c|c|c|c|c|c|c|}
\hline \multicolumn{10}{|c|}{ Coefficients a } \\
\hline \multicolumn{3}{|c|}{ Type of Personnels } & \multicolumn{2}{|c|}{$\begin{array}{c}\text { Unstandardized } \\
\text { Coefficients }\end{array}$} & \multirow{2}{*}{$\begin{array}{c}\begin{array}{c}\text { Standardized } \\
\text { Coefficients }\end{array} \\
\text { Beta }\end{array}$} & \multirow{2}{*}{$\mathbf{t}$} & \multirow{2}{*}{ Sig. } & \multicolumn{2}{|c|}{$\begin{array}{l}\text { Collinearity } \\
\text { Statistics }\end{array}$} \\
\hline ype & C. & (3) & B & $\begin{array}{l}\text { Std. } \\
\text { Error }\end{array}$ & & & & Tolerance & VIF \\
\hline \multirow{4}{*}{$\begin{array}{l}1 \text { IT } \\
\text { Professional }\end{array}$} & 1 & (Constant) & .476 & .105 & & 4.524 & .000 & & \\
\hline & & HRP & .486 & .042 & .551 & 11.715 & .000 & .613 & 1.630 \\
\hline & & EIP & .016 & .035 & .021 & .446 & .656 & .620 & 1.613 \\
\hline & & RCP & .282 & .033 & .326 & 8.417 & .000 & .902 & 1.109 \\
\hline
\end{tabular}

Sources: Authors Calculations using SPSS 21 Version

Plot: 1 Normal P P plot of TR of 350 IT Professionals

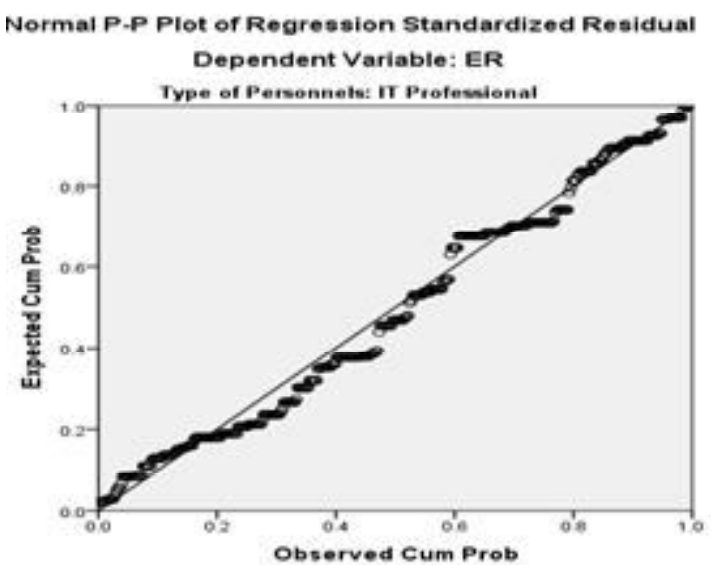

Scattered Plot: 1 Scattered plot of TR of 350 IT Professionals

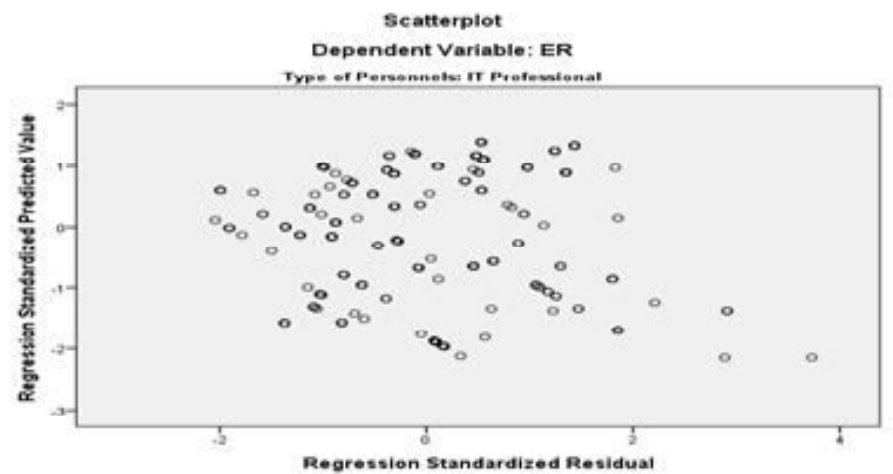




\subsection{INTERPRETATIONOF OBJECTIVE}

Table no. 5 shows the variability among the dependent and independent variables, it shows that HPWBP effects $52.7 \%$ to IT professionals talent retention level. Table no. 6 of ANOVA shows that significance values is less than .05 hence model is quite significant for this study. Table no. 7 of coefficients shows the significance of the variables of HPWBP, as HPWBP involves three major variables i.e. Human Resource practices (HRP), Employee involvement (EIP) and Reward and commitment practices (RCP), hence analysis is also done on these three variables. Significance shows that HRP and RCP are very much significant for the retention of IT professionals as all the values are less than .05. but EIP is not at all important for talent retention.

\section{Hypothesis Testing of OвJective}

H0. There is no significant impact of high performance work based practices on Talent retention (TR).

Main hypothesis is divided in three sub hypothesis and testing is done accordingly.

Table no. 8 Hypothesis testing of the objective

\begin{tabular}{|l|c|c|}
\hline \multicolumn{1}{|c|}{ Null Hypothesis } & $\begin{array}{c}\text { Sig. } \\
\text { Value }\end{array}$ & Result \\
\hline $\begin{array}{l}\text { 1.1 There is no significant impact of human resource } \\
\text { practices on talent retention w.r.t. IT professionals. }\end{array}$ & $.000^{* * *}$ & $\begin{array}{c}\text { Alternate } \\
\text { Hypothesis } \\
\text { Accepted }\end{array}$ \\
\hline $\begin{array}{l}1.2 \text { There is no significant impact of employee } \\
\text { involvement practices on talent retention w.r.t. IT } \\
\text { professionals. }\end{array}$ & .656 & $\begin{array}{c}\text { Null } \\
\text { Hypothesis } \\
\text { Accepted }\end{array}$ \\
\hline $\begin{array}{l}1.3 \text { There is no significant impact of reward and } \\
\text { commitment practices on talent retention w.r.t. IT } \\
\text { professionals. }\end{array}$ & $.000^{* * *}$ & $\begin{array}{c}\text { Alternate } \\
\text { Hypothesis } \\
\text { Accepted }\end{array}$ \\
\hline
\end{tabular}

Sources: Authors calculations using SPSS.21

\subsection{EQUATION FOR TALENT RETENTION}

$$
\text { Equation }=\alpha+\beta 1 \chi 1+\beta 2 \chi 2+\beta 3 \chi 3
$$

Talent Retention of It professionals $=.476+.551(\mathrm{HRP})+.021(\mathrm{EIP})+.326(\mathrm{RCP})$

\section{FINDINGS}

1. In this survey total 350 respondents have participated were IT professionals. 
Modelling the Link between High Performance Work Based Practices and Talent Retention in IT Companies - A Global Prospective Sushma Sharma*, Ajay Kumar Sharma**

2. Out of 350 IT professionals $69 \%$ are male and $31 \%$ are females. Most of the respondents are less than 30 years i.e. $42 \%$. Our $70 \%$ of the respondents are software engineers and $67 \%$ of the respondents have less than 5 years of experience. $40 \%$ of the respondents are post graduates in their respective fields.

3. It has been found that High Performance Work Based Practices has a significant impact on talent retention, as per adjusted $\mathrm{R}$ square it is cleared that independent variable i.e. HPWBP is able to explain $52.7 \%$ variability of talent retention among IT professionals.

4. Not only the overall HPWBP has a significant impact on talent retention, but also the sub variables of HPWBP like reward\& commitment practices and HR practices individually also have significant impact on talent retention. HR practices (HRP) and Reward \& commitment practices (RCP) are important for talent retention in case of IT professionals, but Employee involvement practices (EIP) are not at all significant from the point of view of talent retention.

5. When the employees are compared on the basis of age, it can be seen that the employees with the age group 31-40 (74.57\%) years are very much in sync with the sufficiency of the HPWBP which are followed in the organization, on the contrary employees with less than 30 years $(54.60 \%)$ are comparatively less aware or feel that sufficient HPWBP are not followed in the organization. It is also found that with the increase in the age of employees the satisfaction level has been reduced. Employees less than 30 years $(63.19 \%)$ are more satisfied than employees age more than 40 years (43.69\%). Almost same kind of response has been provided by employees about the effect of HPWBP on employee productivity, it is ranging between $53 \%$ to $59 \%$. On the basis of HPWBP it is difficult to retain employees between age group 31-40 years (34.57\%), on the other hand employees less than 30 years $(65.03 \%)$ can be retained easily.

6. In case of retention an opposite view can be seen only $53.90 \%$ females will stay in the organization on the basis of HPWBP and 56.25\% males will stay in the organization.

7. On the basis of job function, a mixed response can be seen from different job functions, IT consultants have highest perception about sufficient HPWBP i.e. $72.72 \%$, along with the positive perception about talent retention (74.54\%). System analyst has the least positive perception about the adherence of HPWBP i.e. $27.58 \%$, along with talent retention $(51.70 \%)$.

8. In company wise analysis, WIPRO employees are very much in sync with the adherence of HPWBP in the organization i.e. $68 \%$, on the contrary only $52 \%$ employees of Neeraj $\mathrm{S} / \mathrm{W}$ accepted that HPWBP are followed in their organization. Again, in terms of employee satisfaction WIPRO is on the top i.e. $62 \%$ and HCL is on the lowest level i.e. $54.16 \%$. In case of talent retention $62.74 \%$ of HSBC S/W employees would like to stay in the organization, on the contrary only $50 \%$ of the employees of both the companies i.e. NIIT and Neeraj S/W want to stay in the present organization. 


\subsection{Discussion}

The above mentioned analysis and findings shows a clear relationship between dependent and independent variables. The independent variables i.e. high performance work based practices can be termed as organizational and human resource related policies followed in the organization to make an employee feel important, empowered and also feel a sense of belongingness with the organization. Not only this but also provide justified reward and recognition to the deserving employees and to create healthy atmosphere of learning. It clearly shows that if sufficient HPWBP are followed in the organization employees feel satisfied and retained as they see these practices are helpful in providing growth opportunities (Financial \& Non-financial), congenial environment, good relations with seniors \& peer groups, justifiable distribution of work load.

\subsection{RECOMMENDATIONS}

IT industry is regarded as a hub of innovators providing world class technology across the world. It helped in changing Indian economy from agriculture based economy into knowledge driven economy. Now a days Indian IT companies are not confined to domestic level but they are ruling the IT industry across the world. Of course, IT companies are also facing tough competition from other countries like China. Unless the companies employ best HR, practices there shall be a likelihood of deficient growth. As such the IT sector should employ best possible, new and latest HR practices so that retention of skilled professionals should be maximized. The main resource based on which IT companies define their core competencies have always been 'Manpower'. Therefore attracting, selecting, motivating, retaining and developing the knowledge should be the main strategic objective of all the IT companies. With the support of top management, human resource department has decided to bring innovation in human resource practices that is known as High performance work based practices.

\subsection{ConClusion}

Based on the results and findings of the study, the applicability of high performance work based practices in IT company in Delhi\& NCR could be concluded that these innovative practices influence talent retention. It is concluded that adoption of high performance work based practices motivate workers to be more skilful and productive. HPWBP are seen to increase the satisfaction level of the employees and satisfaction leads to high productivity of employees. From the study it was found that high performance work based practices play a key role in the organization and from data collected it is clear that the employees are very much aware about HPWBP that how it works. The results of this study are aligned with the fact that high performance work based practices increases talent retention.

\subsection{IMPLICATIONS OF THE STUDY}

High performance work based practices are influenced by the set of innovative HR practices and for the organization to gain competitive advantage and act globally, mangers must 
Modelling the Link between High Performance Work Based Practices and Talent Retention in IT Companies - A Global Prospective Sushma Sharma*, Ajay Kumar Sharma**

incorporate these practices to improve employee performance. From the findings of the study there is sufficient background to recommend to all IT companies should incorporate these practices in their organization as a matter of concern to gain competitive advantage. The study makes contribution in several ways. By examining the impact of high performance on talent retention, this research explores a condition under which HPWBP works and aligned with the organization objectives.

\subsection{LimitaTiONS OF THE STUdY}

The study is limited in exploring the factors that affect talent retention within the context of IT professionals. It does not cover expatriate managers and project managers who work on foreign assignment. This study focuses on selected Eight IT companies only in

Delhi\&NCR.All findings are based on the information provided by the respondents and are subject to biasness. The scope of the study in limited to selected Eight IT companies of Delhi \& NCR which cannot be applied to different geographical area and provide the same results.

\subsection{SCOPE FOR FURTHER RESEARCH}

This study conclude that high performance work based practices influence talent retention. Every study has its own limitations but each limitation has the scope for further research specially talent acquisition opened to many areas of research. It still does not throw a light on complete scenario of IT industry. This study only explored the impact of high performance work based on talent retention, other factors may also be considered to explain such association such as basic psychological needs. Consequently, future research should explore how psychological needs mediate the effect of high performance work based practices.

\section{REFERENCES}

[1]. Agarwal, N.M., and Thite, M. (2003), "Human Resource Issues, Challenges and Strategies in the Indian Software Industry", International Journal of Human Resources Development and Management, 3(1), pp. 249- 264.

[2]. Appelbaum, E, Bailey, T, Berg, P and Kalleberg, A L (2000) "Manufacturing Advantage: Why highperformance work systems pay off", ILR Press, Ithaca, NY.2(6), pp. 177-185. doi: 10.12691/ajcea-2-6-1.

[3]. Sung, J and Ashton, D. (2005) High Performance Work Practices: Linking strategy and skills to performance outcomes, DTI in association with CIPD.

[4]. Sung-Choon, H. K. (2013). "Strategic HR functions and firm performance: The moderating effects of high-involvement work practices" Asia Pac J Management journal,

[5]. Sun, L. Y., Aryee, S., \& Law, K. S. (2007). "High-performance human resource practices, citizenship behavior, and organizational performance: A relational perspective." Academy of Management Journal, 50(3), pp. 558?577.

[6]. S. Wood, (1995). The four pillars of HRM: Are they connected? Human Resource Management Journal, 5(5), pp. 49-59.

[7]. Ramlall, S. J. (2009). Continuing the HR Evolution: Building Resilience in Turbulent Economic Times. International Journal of Global Management Studies, 1(3), pp.11-16. 
Modelling the Link between High Performance Work Based Practices and Talent Retention in IT Companies - A Global Prospective Sushma Sharma*, Ajay Kumar Sharma**

[8]. Pritchard, R.D. (1992), Organizational productivity, Dunnette, M.D. \& Hough, L.M. (Eds.) Handbook of Industrial/Organizational Psychology, Palo Alto, CA: Consulting Psychologists Press, 3(2), pp. 443471.

[9]. Tamkin, P. (2004). High Performance Work Practices, Institute of Employment Studies.

[10]. Surya Narayana Reddy, Narayana Reddy, Viswanatha Reddy (2019), "Impact of General Climate, HRD Mechanism and 'Octapace' Culture on Employee Job Satisfaction" SUMEDHA Journal of Management, Vol 8, No 1, PP (69-78)

[11]. Padala, S.R. (2014), "Human Resource Practices in Voluntary Organizations" SUMEDHA Journal of Management, 3(2), pp. 12-19 